\title{
ACCOUNTING EDUCATION, SOCIALIZATION AND THE ETHICS OF BUSINESS
}

\author{
John Ferguson $^{1^{*}}$, David Collison ${ }^{2}$, David Power ${ }^{3}$ and Lorna Stevenson ${ }^{4}$
}

1. *Corresponding Author: Lecturer in Accounting and Finance, School of Management, University of St. Andrews, Scotland, KY16 9SS, UK, Tel: + 44 (0)1334 462809, Fax: +44 (0)1334 462812, e-mail: jf60@st-andrews.ac.uk

2. Professor of Accounting and Society, School of Accounting \& Finance, University of Dundee, Scotland, DD1 4HN, UK, Tel: + 44 (0)1382 384192, Fax: + 44 (0)1382 388421, e-mail: d.j.collison@dundee.ac.uk

3. Professor of Business Finance, School of Accounting \& Finance, University of Dundee, Scotland, DD1 4HN, UK, Tel: +44 (0) 1382 384854, Fax: + 44 (0)1382 388421, e-mail: d.m.power@dundee.ac.uk

4. Senior Lecturer in Accounting, School of Accounting \& Finance, University of Dundee, Scotland, DD1 4HN, UK, Tel: +44 (0) 1382 384196, Fax: + 44 (0)1382 388421, e-mail: 1.a.stevenson@dundee.ac.uk 


\title{
ACCOUNTING EDUCATION, SOCIALIZATION AND THE ETHICS OF BUSINESS
}

\begin{abstract}
This study provides empirical evidence in relation to a growing body of literature concerned with the "socialization" effects of accounting and business education. A prevalent criticism within this literature is that accounting and business education in the UK and US, by assuming a "value-neutral" appearance, ignores the implicit ethical and moral assumptions by which it is underpinned. In particular, it has been noted that accounting and business education tends to prioritise the interests of shareholders above all other stakeholder groups. The paper reports on the results of a set of focus group interviews with both undergraduate accounting students and students commencing their training with a professional accounting body. The research explores their perceptions about the purpose of accounting and the objectives of business. Findings suggest that both university and professional students' views on these issues tend to be informed by an Anglo-American shareholder discourse, whereby the needs of shareholders are prioritised. Moreover, this shareholder orientation appeared more pronounced for professional accounting students.
\end{abstract}

KEY WORDS: accounting, Anglo-American capitalism, ethics education, ideology, shareholder wealth, socialization 
"By propagating ideologically inspired amoral theories, business schools have actively freed their students from any sense or moral responsibility" (Ghoshal, 2005, p.76).

"Perhaps the best way... of making students aware of the contingent nature of many of the prescriptions and axioms that their courses take for granted, might be a course on comparative capitalisms" (Dore, 2006, p.18).

\section{Introduction}

There is a growing concern within the extant literature that accounting and business education in the UK and US is failing to develop students' ethical maturity. While much of this research points to the lack of, or need for, business ethics courses which address professional codes of ethics, or ethical decision making (Bampton \& Cowton 2002, Bampton \& Maclagan 2005, Beu et al. 2003, Bishop 1992, Cohen \& Pant 1991, Cohen et al. 2001, Gandz \& Hayes 1988, Gowthorpe et al. 2002, Lombardi 1985, McDonald 2005, Sims \& Sims 1991), a number of studies have drawn attention to two further, arguably more fundamental, ethical issues. More specifically:

(i) accounting and business education, by assuming a "value-neutral" appearance, fails to acknowledge and address the ethical and moral assumptions which underpin it;

(ii) accounting and business education fails to acknowledge alternative frameworks which are guided by different sets of ethical and moral assumptions.

In terms of the failure to acknowledge the value-laden nature of what gets taught on accounting and business courses, it has been suggested that accounting and business education can be described as a site of socialization, whereby students are inculcated with a particular worldview which draws on the values and assumptions of AngloAmerican capitalism ${ }^{1}$ (Frankfurter \& McGoun 1999, Collison 2003, Dore 2006, 
Ellsworth 2002, 2004, Everett 2007, Ferguson et al. 2005, 2007, Ghoshal 2005, Gray et al. 1994, Neimark 1995, Perriton 2007, Schleef 1998, Springett 2005, Waddock 2004, 2005, Wolfe 1993). In particular, it has been noted that accounting and business education reproduces and sustains the notion that society's welfare is optimised as a result of individuals acting in their own economic self-interest, and that the only participants in the wealth creating process that should have their interests maximised are shareholders (Collison 2003, Collison \& Frankfurter 2000, Ellsworth 2004, Everett 2007, Ferguson et al. 2005, 2007, Gray et al. 1994, Waddock 2005, Wolfe 1993). According to Ellsworth (2004: 66), the "dogma" of business education in terms of propagating the "near religious... belief that maximization of shareholder wealth is a corporation's reason for existence" comes at the "expense of moral courage and inspirational purpose". Moreover, accounting and business students are not encouraged to consider alternative ways in which society may be organised, or to speculate upon the power asymmetries which underpin the prevalent worldview that they encounter. Indeed, educators who attempt to introduce an alternative set of beliefs tend to be marginalised (Ellsworth 2004, Ghoshal 2005).

In terms of the lack of consideration given to other frameworks, critics of business and accounting education have suggested that restricting learning in this way, without offering an alternative perspective from which students can exercise their own reasoning ability is, in a sense, “indoctrination" (Loeb 1988, 1991, Van Dijk 1998), the propagation of ideology (Ferguson et al. 2005, 2007, Ghoshal 2005, Mir 2003) and encourages moral "atrophy” in students (Gray et al. 1994, Loeb 1991). Moreover, the contestability of the "Anglo-American" framework in accounting and business education is apparent by the very existence of alternative economic frameworks to be found in continental Europe and Japan. These alternatives typically 
favour a more balanced approach in terms of addressing the interests of a range of stakeholders and, traditionally, do not accord primacy to shareholders or to the maximisation of shareholder value. For example, Hutton (1996: 263) notes that while social market Europe may conform to "market imperatives" there remains a "partnership between labour and capital". This "mitbestimmung (or co-decision making) at both board and work council level" means that management relinquish the "right to run business autocratically in favour of the shareholders' narrow interests" (Hutton 1996: 263; see also Collison 2003, Dore 2006).

One could also argue that students ought to be exposed to alternative economic frameworks in light of social indicator research which suggests that AngloAmerican economies, where a shareholder orientation is prevalent, are characterised by income inequality (Collison et al. 2007, Wilkinson 2005). Such research has drawn attention to the link between income inequality, various health issues and violent crime - for example, income inequality has been variously linked with psychosocial factors such as depression, anxiety and drug use (Wilkinson 2005, Wilkinson \& Pickett 2009), child mortality (Collison et al. 2007) and gun crime (Kennedy et al. 1998). Moreover, given that the emphasis on maximisation of shareholder wealth, as both an objective of business and a governance mechanism, has been implicated in the current financial crisis, a further reason for encouraging business students to evaluate alternative economic perspectives may be advanced. It is perhaps noteworthy that the Financial Times, a hitherto defender of "shareholder capitalism", has recently questioned the merits of this system. As part of series entitled the "Future of Capitalism", the Financial Times has published articles which have argued that:

"the financial system has proved dysfunctional, how far can we rely on the maximisation of shareholder value as the way to guide business?... Events of the past 18 months must confirm the folly of this idea... As a defective financial 
sector loses its credibility, the legitimacy of the market process itself is damaged. This is particularly true of the free-wheeling "Anglo-Saxon" approach.” (Wolf 2009)

While acknowledging the limitations of a maximisation of shareholder wealth model, some contributors to the Financial Times series have recommended embracing alternative models of capitalism. For example, Pilling and Atkins (2009) state, 'Nordic economies' social welfare systems could offer lessons to the rest of the world on how to reduce worker anxiety at a time of crisis and rapid change and on enabling economies as a whole to restructure" ${ }^{\text {. }}$

Therefore, at the very least, it has been argued that Anglo-American accounting and business education should be "open to other options" (Ellsworth 2004: 67). As Neimark (1995) contends, such a restricted approach to learning and teaching in Anglo-American countries serves merely to "naturalize" the status-quo by treating deeply contestable underlying ethical assumptions as incontestable or universal. It is in this respect that Alvesson \& Willmott (1996: 204) refer to Business Schools as "key socializing agencies for the intelligentsia of advanced capitalist societies".

A number of researchers have suggested that this constrained approach to accounting and business education essentially limits the supposed benefits of add-on courses in business ethics (i.e. the implicit approach adopted by much of the business ethics literature). For example, Wolfe (1993: 2) argues that:

"If we look at many of the cases we find in business ethics textbooks, we see that the protagonists are non-malevolent, ordinary people in middle or upper management who usually act within a corporate hierarchy. The act itself, the one identified as being the cause of a death or of some grave social harm, is the result of managers doing essentially what they were taught to do!... In the eyes of students, our course in business ethics is interesting but really does not challenge the substantial intellectual conditioning in the "functional areas" of business at universities and in society at large. In [terms of the] long-term 
impact on our students or our business culture, the course is way too little, way too late".

In other words, according to Wolfe (1993), providing "bolt-on" courses in business ethics for accounting and business students is a limited activity, if the ethical and moral assumptions underpinning mainstream or "functional" material are not addressed (Cunliffe et al. 2002, Perriton 2007, Wolfe 1993). Similarly, Ghoshal (2005) asserts that additional courses in business ethics have a limited effect because they do not sufficiently challenge the underlying "common sense" assumptions which help maintain and reproduce current social arrangements ${ }^{3}$. He states:

"If deans really intend to infuse a concern for ethics and for responsible management in the research and teaching that are carried out at their institutions, they have to acknowledge that the tokenism of adding a course on ethics will not achieve their goals. As long as all the other courses continue as they are, a single, stand-alone course on corporate social responsibility will not change the situation in any way" (Ghoshal 2005: 88).

In the case of accounting education, it has been argued that the contestable assumptions of Anglo-American capitalism are dissimulated ${ }^{4}$ through the "guise of technical rationality" (McPhail \& Gray 1996: 27). In this sense, accounting education "fulfils a crucial economic role in the maintenance of liberal neo-classical economics" which it achieves through its presentation of accounting as an innocuous technical process (McPhail \& Gray 1996: 28-29; see also, Gray et al. 1994, Humphrey et al. 1996). According to Collison (2003: 861):

"Attention to the interests of shareholders above all other groups is implicit in much of what is taught to accounting and finance students. The very construction of a profit and loss account... is a continual, and usually unstated, reminder that the interests of only one group of stakeholders should be maximized".

Moreover, Collison (2003: 861) argues that, "it may be very difficult for accounting and finance students to even conceive of another way in which affairs could be 
ordered... even at the algebraic level, let alone the moral". However, as Waddock (2005: 147) points out, accounting is an "ethical, rather than a technical, discourse", adding:

"If we want accountants who are capable of acting with integrity and understanding the broader system in which they work, we must teach them to be mindful - aware of their belief systems, conscious of consequences, and capable of thinking broadly about the impact of their actions and decisions" (emphasis added)".

The aim of the present paper is to explore whether, or the extent to which, students' ethical and moral thinking is informed by an Anglo-American shareholder discourse. In addressing this aim, this study ascertains students' views on: (i) the users for whom they believe accounting information is prepared, and (ii) the objectives of business (or more specifically, the constituencies for whose benefit business activity is undertaken). By drawing on students' rationales and justifications regarding these issues, this exploratory study investigates whether a particular worldview is prevalent among accounting students and the extent to which they are aware of alternative perspectives. The following section outlines the method and context for this study.

\section{Method and Context}

In order to explore accounting students' views regarding the users of accounting information and the objectives of business, focus group interviews were undertaken with two cohorts: first year undergraduate accounting students and students commencing their training with a professional accountancy body. Both groups were interviewed at the end of their initial course in financial accounting. The focus groups were undertaken at four separate research sites; at three university institutions and with professional trainees from one of the major accounting bodies in the UK. The focus group interviews were part of a larger investigation into the 
ideological characteristics of accounting education. As part of the larger project, a two-stage questionnaire was distributed at four separate sites: the four sites which are also the focus of the present study ${ }^{5}$. The questionnaire explored students' perceptions of the purpose of accounting information, the objectives of business and their recommended course material, at both the start and end of an introductory course on accounting. Respondents to the questionnaire were invited to contact the lead author if they were willing to participate in a focus group interview. Focus group interviews with students were subsequently arranged from a list of those responding to this invitation.

Each focus group varied in terms of the number of students present and the gender mix. Contextual information regarding the research sites and the composition of the focus groups is provided in Table 1. Each focus group lasted one hour, and all four focus group meetings were recorded and transcribed. All of the focus group meetings were attended by two members of the research team who distributed a list of questions for guiding the discussion. Interjections by the researchers were kept to a minimum and were only made after significantly long pauses in the focus group participant contributions (Krueger \& Casey 2000). Probing questions were used when participants comments were ambiguous or to encourage further clarification. Care was taken during the focus group discussions to manage "dominant talkers" and to encourage shy respondents: more specifically, the use of body language and the more "frontal tactic of verbally shifting attention", was employed when necessary (Krueger \& Casey 2000: 111).

Insert Table 1 about here 
There are important methodological reasons for approaching the study in this way. Drawing on the sociology of education literature, and, in particular, the work of Apple (2004), one must be careful not to view the education process in terms of a simplistic "input-output" model - i.e. where students (the input) become socialized by an ideological curriculum that reflects the interests of dominant groups within society and go on to reproduce those values in varying aspects of their lives (the output). Research in this tradition often speculates on the consequences of the educational process by analyzing the content of the curriculum alone - i.e. without attending to the views and understanding of the participants in the process. Moreover, according to Apple (2004) such a perspective overlooks a number of pertinent issues; more specifically, it fails to consider the role of contestation and the contingent possibility that students may resist or appropriate the ideological messages they encounter (Apple 2004, Thompson 1990).

Similarly, as Thompson (1990) delineates, if one is exploring the ideological character of a media message (or in this case, an educational process), it is important to look, not only at the content of the message (or process), but also to consider aspects of production and reception (see Ferguson 2007 for an overview of this framework). As discussed above, the findings presented in this paper are a part of a larger study into the ideological character of recommended accounting materials. Drawing on Thompson's (1990) depth-hermeneutical framework, this larger body of work has considered the production, content and reception of recommended course material. While findings from this larger body of work have reported specifically on the production of recommended materials (Ferguson et al. 2006) and their content and reception (Ferguson et al. 2008), this study focuses on students' views regarding the 
users of accounting information and the objectives of business in general. In summary, it is not simply enough just to assume that because a course or a degree programme is underpinned by a particular perspective, that students will become socialized in to that way of thinking (which is the implicit assumption in many of the criticisms of accounting and business education) - instead, one must take into account the ways in which students interpret, understand and appropriate the messages they receive (Thompson 1990).

The remainder of this paper is structured as follows: The following section reports on the results of four focus group investigations; these were undertaken at the three academic institutions as well as in the office of an accountancy firm. The results of the focus groups will be discussed under the following headings: users of accounting information; alternative perspectives/other users; in whose interests are companies run?; and the objectives of business. The final section summarises the results and concludes.

\section{Findings}

\section{Users of accounting information}

Students were first of all asked to identify, for whom, from a list of possible users of accounting information, they thought financial statements were prepared. The list of stakeholders was derived from the International Accounting Standards Board's, Framework for the Preparation and Presentation of Financial Statements and included present and potential investors, employees, lenders, suppliers and other trade creditors, customers, governments and their agencies and the general public (International Accounting Standards Committee Foundation, 1989). Responses were consistent across each group, with shareholders being identified as the principal users 
by the majority of participants. For example a typical response, from Student A1, indicated that:

Shareholders... because technically they own the company and they will want to know how their investment is doing.

Student B1 agreed when he noted that "advisors and shareholders" were the main users. Student C1 was even more emphatic when he stated that:

I think the shareholders - that's why you need to make a profit, to pay the shareholders.

Professional students' responses did not differ from their university student counterparts, with shareholders being identified as the principal target for accounting information. For example, Student P1 explained:

I see accounts being prepared for shareholders or for whoever owns the business for whatever purposes they want... Shareholders generally don't have a hand in the running of the business, so the accounts let the shareholders see how [management] are doing.

Similarly, Student P3 noted that "managers have a responsibility to the owners of the business" implying that managers prepare financial accounts primarily for shareholders. Even when other possible users were identified by students, it was because they were deemed to share the owners' goals, normally by virtue of being shareholders themselves. Thus, Student A2 suggested that:

Some employees might hold shares in the company... so they might want to know whether they should sell their shares in the company... or to encourage employees to buy shares.

Similarly, Student C2 argued that "a lot of employees [will be] shareholders anyway... so I think it is quite important for them as well”. Students were asked to differentiate between what they deemed to be current practice in the production of financial statements, and to comment on whom they felt these should be prepared 
for. In most cases, the question elicited a similar response. For example, Student A5 stated that:

I think primarily for shareholders, because they own the company and have put their money in the company. They have more of a financial interest, whereas the other interest groups don't have such a financial interest.

Student C2 concurred with this view when he noted that "the shareholders are the most important ones". Similarly, all of the professional students identified shareholders as the constituency for whom financial statements should be prepared. For example, Student P3 noted that, "it depends on the type of company and on their business agenda" adding "if it is a purely profit driven company, then the accounts will matter to [the shareholders] more than the general public or the government".

When the participants were asked why they felt that the shareholders were the most important group, they typically pointed to the financial interest which shareholders have by virtue of their ownership of the company. Thus Student B3 argued that shareholders were the main users since "they've got a financial interest", while Student B4 justified the choice because "[shareholders] own the company". Student C2 made a similar decision in favour of shareholders "because they're the ones that put the equity into the business".

Students were asked to contemplate whether employees also had a financial interest in a company. Respondents tended to draw a distinction between the employee and the shareholder on the basis of risk: since the employee enjoyed a steady flow of income in the form of a salary/wage, shareholders were deemed to be at a greater risk of losing their investment if the company failed. Therefore, Student A5 stated that: 
Most employees will not have much interest in the annual reports of a company. As long as they were getting a wage at the end of the month. Most of them won't be interested in the company report.

Student B4 agreed when he noted that:

At the end of the day, the shareholders are putting in the initial investment, whether it's buying initial shares or reinvesting in more shares. I am assuming their initial investment will be much more than an employee. [Employees] are investing their time and effort, and they are getting remunerated for that. Investors don't get anything back unless the company is successful.

\section{Alternative perspectives/other users}

Not all participants agreed that shareholders should be the main focus of company financial statements. In all three of the University groups, there was typically one group member who felt that a wider range of users should be considered, or that particular user groups should feature more prominently. For example, in the first group, Student A3 argued that:

Although shareholders are important, creditors are probably more important, because at the end of the day, they are going to decide whether you [remain in business].

In the second group, Student B1 also suggested that the needs of stakeholders other than shareholders should be addressed by companies:

You've got to count the rest of them... Loan creditors want to know what their business is about and if they can afford to pay them back. I think [financial statements] should be focused towards the shareholders - but they should also include more information so that other groups will benefit from them as well... like something that employees could benefit from, or other groups. So it is not solely aimed at just the shareholders.

When asked to consider whether companies should produce information other than financial information in their annual reports, participants were quick to point out that 
non- financial information would be of benefit to users other than shareholders, such as customers and the general public. For example, Student A5 stated that:

Some customers may be interested in the social and environmental side [of the business], especially oil companies like Shell, whose company report has a lot of environmental stuff in it. They might be more interested in that rather than the financial side of the company.

Student B4 agreed and noted that:

If you were sort of an ethical consumer and you wanted to know the trading policies that a company had... whether they outsourced manufacturing to a foreign country ... My wife's like that. She didn't like buying Nike because of the fact that they use the factories and the wee kids to produce their Nike branding. She wants to help the planet. She's a health visitor.

This view was supported by student $\mathrm{C} 4$ who argued that:

People are more interested in the ethical side of business these days; they are interested in the accounts and stuff but I think it's got more important to people, you know environmental issues and things like that... I think the general public would understand that [information] more than financial documents because I think your average person on the street... I don't think they would know where to look to be able to get hold of financial documents and then second of all, I don't think they'd understand them unless they had some sort of accounting or financial background... they'd be more likely to understand the ethical sort of side of things.

However, whilst focus group participants were aware that customers and the wider public were interested in social, environmental and ethical information pertaining to companies, Student B5 asked, "but is that really accounting information?". Indeed, despite identifying the wide range of information that other stakeholders would benefit from, the majority of participants still maintained that company financial statements should be produced for shareholders. They seemed to have difficulty in conceiving of how alternative annual reports might be constructed or whether the current structure of financial statements was appropriate for other stakeholder groups. 
Unlike the university focus groups, there was less evidence of any professional trainees holding an alternative perspective about who financial statements should be prepared for. However, Student P4 noted that:

For public companies, in my small person's view of things, you would like to see transparency through everything. That would be the ideal, but it is never going to happen. I think for small businesses which don't really have much effect over a big area, then it is not so necessary.

In whose interests are companies run?

Despite identifying shareholders as the principal users of accounting information, students from University A did not identify shareholders as the group for whom companies were run. For example, Student A5 stated that companies should be run primarily in the interest of customers:

If you take care of the customer the business will take care of itself. If you keep your customers happy, they will keep on coming, and that means you can keep on your employees.

Students at Universities B and C made the link between the principal users of financial statements, and the interests for which they perceived companies were run identifying shareholders in each case. Thus, Student B3 commented that, "it all comes back to shareholders, doesn't it? Getting their worth." In addition, Student C5 noted that "In a corporation there seems to be an emphasis that the shareholders are the people that you're doing it for". Like the university students interviewed, professional trainees identified shareholders as the group for whom companies are run. In their remarks, professional students alluded to their training materials as the source for their views. For example, Student P1 stated,

We are told in our... notes [on our first module] that directors run the business in the best interests of the shareholders. 
Perhaps by virtue of companies being constructed as separate legal entities, a number of students viewed the company as an abstract entity which pursued its own interests, and which was run essentially for itself. The comments of Student A5 typified this view, when she stated that "[Companies are run for] themselves. I think it is in the company's own interest to make a profit".

On a few occasions, students had to be pushed to identify groups or individuals that would benefit from a company's pursuit of profit. A striking aspect of this perspective, is that by constructing the company as an abstract legal entity, the interests which are served as the result of corporate activity are somewhat obscured. An example of this obscuring of interests was given by a student at University A. When asked, in whose interests do you think companies are run, Student A1 replied:

I would suggest... the upper tier. Your directors, the upper managers. The directors will establish on high what performance targets should be reached and then that gets passed down the line.

When asked what she thought drives the target setting process, she replied "Money. You hit more targets, you get more money.” Again, target setting was not associated with the interest of any particular constituency, but attributed to a more abstract cause - money.

Students were asked to differentiate between whose interests they thought companies were run for, and for whose interests they felt companies should be run. Again, responses were similar, with shareholders being identified as the main interest group served by corporate activity. For example, Student C3 stated that:

The shareholders... because they're the ones that put the equity into the business.

Similarly, Student P3 explained:

Maximising shareholder wealth... if you are putting money into a company to begin with, you are doing it for two reasons. One, to make money. The other is just to have part ownership. 
The Friedmanite argument, that by pursing the interest of shareholders, other stakeholders will benefit was invoked by Student B5 to justify their view:

If the shareholders want to maximise wealth... they might try and expand the business. More job opportunities, more job security. So, pursuing the best interest of shareholders also helps employees.

\section{Objectives of business}

Students were asked to comment on what they thought the objectives of a business were. In this sense, an attempt was made to examine whether students identified the objectives of business with a particular constituency; i.e. whether they recognised a link between the objectives of business and the interests of those for whom companies were run (as outlined in the previous section). Despite most students having identified shareholders as the main users of accounting information, and those in whose interests companies were run, the business objectives they identified varied considerably. A notable feature of many of the responses from university students was that business objectives tended to be viewed in an abstract sense and, in most cases, were not linked to any particular constituency. Views emerged which were similar to those expressed in the discussion about whose interests companies were run; in this respect the identity of constituents who may shape the objectives of business, or who may benefit directly from a specific objective, was somewhat obscured. Respondent A2 suggested that the primary goal of a firm was:

To maximize profit. I think that is the main objective of every business. Without profit, the company will not survive.

This conflation of views is noteworthy, since this student appears to equate the view that the objective of business is to make profit in order to survive, with the idea that 
profit has to be maximised. Student A2 was not the only student to conflate these views; for example, Student P3 also stated:

The norm is that most companies are set up to make a profit... the goal is to make as much money as possible for most businesses.

Students A1 and B2 were more succinct when they stated that a firm's objective was, "to make money" and "survival" respectively. Student C3 agreed when she pointed out that "business is set up to make a profit really or you wouldn't do it", while Student C1 made the same point slightly differently when he argued that "probably the first objective is to break even so that you're not making a loss before you start". Only one university student linked the objectives of business with a particular constituency: the customer. Specifically, Student C2 argued that the objective was:

Mainly to provide a service to customers. I think that's what it is to provide a service to customers, I think that's the main objective of the business but sometimes also to maximise profit.

Unlike the university students interviewed, the professional students tended to make the link between those in whose interests companies were run and the objective of business. For example, Student P1 stated:

To maximise shareholder wealth, which they may achieve by increasing their market share, or whatever method they pursue, but the overall objective will be to maximise shareholder wealth.

Similarly, Student P3 explained that "the main objective of business is to maximise shareholder wealth" although he did point out that "it depends on what the company was set up for". When asked if they felt the maximisation of shareholder wealth was an appropriate objective, the majority of professional students indicated that they agreed with this aim. However, Student P4 noted that: 
I understand you have to make money, but it is a very insular objective... I do think companies should have other objectives, but, realistically, the more profitable they are, the more they are going to succeed.

\section{Conclusion}

This paper has outlined the results of our investigation into accounting students' perceptions about the purpose of accounting and the objectives of business. Results from the focus group interviews with students provide evidence that, not only is a shareholder emphasis apparent within accounting education, but that students tend to prioritise the interests of shareholders above all other stakeholder groups. In many respects, this worldview was notable when students were asked to identify the group for whom financial statements should be prepared; in particular, it was assumed by the majority of students that shareholders have the rights to company information by virtue of the fact that they are the owners. Furthermore, most students assumed that shareholders have a more significant financial interest in companies than do employees. While university students identified shareholders as the constituency for whom financial statements should be prepared, they tended to articulate a fairly abstract notion regarding the primary objective of business. For example, it was suggested by a number of university students that businesses should make profits for themselves; in other words, university students tended to view the business organisation as an abstract entity which pursued its own interests, and did not identify any particular constituency which would benefit from this profit seeking behaviour. In this respect, one could argue that the accounting education process at university may somehow obfuscate social relationships and obscure the individuals or groups that benefit from economic activity. Thompson (1990) suggests that this process, whereby power asymmetries are obscured and concealed, may be considered a mode of ideology - which he refers to as "dissimulation". 
While university students tended to articulate a more abstract view regarding the objectives of business, professional students were more unequivocal, stating that the principle objective of business was to maximise shareholder wealth. In this respect, professional students identified shareholders as the group for whom financial reports should be prepared, as the group for whom businesses should be run, and the group whose wealth should be maximised. These findings would suggest that while both university and professional students exhibit a preference for privileging the interests of shareholders, a shareholder focus was much more prevalent among professional students.

A limitation of the study, which is worth highlighting at this point, is the lack of knowledge of the background characteristics of individuals students, whether already attending university or engaged in professional training. Similarly, individuals own rationales for positions held was not teased out beyond what may be inferred from their contributions in the group setting.

It is worth mentioning that both university and professional students, on occasion, conflated the differing business objectives of making profit and maximising profit. As Dore (2000) argues, the differences in these objectives, as well as their social consequences, are considerable. For example, Dore (2000: 10) refers to welfare capitalist economies (such as Germany and Japan) which tend to balance the interests of a wider group of stakeholders and have "more pluralistic criteria of human welfare for measuring progress towards the good society". Companies in such countries may pursue profit as an objective of business but will, according to Dore (2000), forgo the maximisation of profit in order to address the "rights" of a range of stakeholders. By contrast, Anglo-American/Stockmarket economies are characterised by firms "run primarily, or even exclusively, for the benefit of shareholders" (Dore 2000: 10). Such 
firms tend to pursue the maximisation of returns, often at the expense of labour and other stakeholder groups (Dore 2000, Doyle 1994). According to Dore (2000) AngloAmerican economies are characterised by a less egalitarian distribution of wealth and vast economic inequality (see also Collison et al. 2007).

One of the reasons for undertaking focus group interviews with accounting students in this study was to respond to Apple's (2004) assertion that one should not speculate upon the consequences of the educational process by attending to the content of the curriculum alone. In this respect, Apple (2004) suggests that there is a possibility that ideological messages may be resisted by students. In each of the four focus groups conducted for this study, there tended to be one dissenting voice, who, typically, suggested that financial statements should be prepared for a wider range of users. However, while a limited element of 'contestation' was apparent, this appeared to be confined to discussions concerning the users of accounting information, and was generally not extended to considerations regarding the interests in which companies are run or the objectives of business.

Findings from this research provide some evidence that accounting students' views regarding the purpose of accounting information and the objective of business are informed, to a large extent, by a specific worldview underpinned by maximisation of shareholder wealth assumptions. Furthermore, this was much more evident for professional accounting students. A possible explanation for these findings can be made by reference to the conclusions already delineated in a number of other studies: namely, that accounting and business education fails to address the ethical assumptions that it is underpinned by, and fails to acknowledge alternative ethical frameworks (Collison 2003, Everett 2007, Ferguson et al. 2005, Gray et al. 1994). 
According to Wolfe (1993), one can begin to address these criticisms by making explicit "the moral principles of capitalism" on accounting and business courses. As Everett (2007: 262, emphasis in original) points out, many accounting and business faculty assume that ethics or ethical assumptions are not a part of what they teach. A consequence of such assumptions is that:

"By not challenging the private interests of profit maximization for shareholders, this field's cultural goods producers acquiesce to the field's dominant, relativistic/egoistic vision. They in effect role model two forms of ethics: subjective ethical relativism and individual ethical egoism. The former is based on the idea that morality is in the eye of the beholder... the latter is based on the (partial and absurd) idea that moral rightness is what is good for me"

By making the underlying ethical assumptions of accounting and business more explicit, as opposed to, for example, obscuring them in the guise of technical rationality, students would become better placed to develop their own ethical reasoning abilities (Dore 2006, Gray et al. 1994). Further, by addressing these underlying assumptions, faculty would also be better positioned to "teach alternative models... that are not particularly complex or difficult to learn" (Everett 2007: 262). Dore (2006) suggests that one way of introducing students to alternative ethical perspectives is by teaching a course on comparative capitalism or political economy. In this sense, Dore (2006: 18) argues that students would, at the least, become aware that the economy does not necessarily have to "work on the basis of self-interested behaviour" and that "self-interested rationality is itself a cultural product". By raising awareness of the ethical assumptions which underpin different economic structures, Dore (2006: 20) expresses the hope that business schools may "produce at least a handful of people capable of playing the role of independent public intellectual in their societies" ${ }^{\prime 6}$. The findings of the current paper would suggest that UK accounting and business education may need to change if this hope is to be achieved. 


\section{References}

Alvesson, M. \& Willmott, H. 1996. Making sense of management: a critical introduction. London: Sage.

(ASC) Accounting Standards (Formerly Steering) Committee. 1975. The Corporate Report. London: ICAEW.

Apple, M. 2004. Ideology and the Curriculum (3e). London: Routeledge.

Bampton, R. \& Cowton, C.J. 2002. 'The teaching of ethics in management accounting: progress and prospects.' Business Ethics: A European Review, 11: 1, $52-$ 61 .

Bampton, R. \& MacLagan, P. 2005. 'Why teach ethics to accounting students? A response to the sceptics.' Business Ethics: A European Review, 14: 3, 290-300.

Beu, D.S., Buckley, R. \& Harvey, M.G. 2003. 'Ethical decision making: a multidimensional construct.' Business Ethics: A European Review, 12: 1, 88-107.

Bishop, T.R. 1992. 'Integrating business ethics into an undergraduate curriculum.' Journal of Business Ethics, 11:4, 291-299.

Cohen, J.R. \& Pant, L.W. 1991. 'Beyond bean counting: establishing high ethics standards in the public accounting profession.' Journal of Business Ethics, 10:1, 4556.

Cohen, J.R., Pant, L.W. \& Sharp, D.J. 2001. 'An Examination of Differences in Ethical Decision-Making Between Canadian Business Students and Accounting Professionals.' Journal of Business Ethics, 30:4, 319-336.

Collison D.J. 2003. 'Corporate propaganda: its implications for accounting and accountability.' Accounting Auditing and Accountability Journal, 16: 5, 853-886.

Collison, D.J. \& Frankfurter, G.M. 2000. 'Are we really maximising shareholders wealth? or: what investors must know when we do.' The Journal of Investing, 9: 3, $55-62$.

Collison, D.J., Dey C., Hannah G. \& Stevenson L.A. 2007. 'Income inequality and child mortality in wealthy nations.' Journal of Public Health, 29: 2, 114-117.

Cunliffe, A., Forray, J.M. \& Knights, D. 2002. 'Considering management education: insights from critical management studies.' Journal of Management Education, 26: 5, 489-495.

Dore, R. 2006. 'The important and the unimportant in business education.' Asian Business and Management, 5: 1, 9-21. 
Dore, R. 2000. Stock Market Capitalism: Welfare Capitalism. Oxford: Oxford University Press.

Dore, R., Lazonick, W. and O’Sullivan, M. 1999. 'Varieties of Capitalism In The Twentieth Century.' Oxford Review of Economic Policy, 15:4, 102-120.

Doyle, P. 1994. 'Setting business objectives and measuring performance', Journal of General Management, 20:1, 1-20.

Ellsworth, R. 2004. 'The corrosion of corporate purpose.' BizEd, March/April, 66-67.

Ellsworth, R. 2002. Leading With Purpose: The New Corporate Realities. California: Stanford University Press.

Everett, J. 2007. 'Ethics education and the role of the symbolic market.' Journal of Business Ethics, 76:3, 253-267.

Felton, E.L. \& Sims, R. 2005. 'Teaching business ethics: targeted outputs.' Journal of Business Ethics, 60:3, 377-391.

Ferguson J. 2007. 'Analysing accounting discourse: avoiding the fallacy of internalism'. Accounting, Auditing and Accountability Journal, 20:6, 912-934.

Ferguson, J. Collison, D.J., Power, D.M. and Stevenson LA. 2008. An analysis of the role of the textbook in the construction of accounting knowledge. Edinburgh: ICAS.

Ferguson, J., Collison, D.J., Power, D.M. \& Stevenson, L.A. 2007. 'Exploring accounting educators' perceptions of the emphasis given to different stakeholders in introductory textbooks.' Accounting Forum, 31: 2, 113-216.

Ferguson, J., Collison, D.J., Power, D.M. \& Stevenson, L.A. 2006. 'Accounting textbooks: exploring the production of a cultural and political artefact.' Accounting Education: an international journal, 15: 3, 1-18.

Ferguson, J., Collison, D.J., Power, D.M. \& Stevenson, L.A. 2005. 'What are recommended accounting textbooks teaching students about corporate stakeholders?' British Accounting Review, 38:1, 23-46.

Frankfurter, G.M. \& McGoun 1999. 'Ideology and the Theory of Financial Economics.' Journal of Economic Behaviour and Organization, 39, 159-177.

Gandz, J. \& Hayes, N. 1988. 'Teaching business ethics.' Journal of Business Ethics, 7: 9, 657-669.

Glenn, R. Jr. 1992. 'Can a business and society course affect the ethical judgment of future managers?.' Journal of Business Ethics, 11:3 217-223.

Ghoshal, S. 2005. 'Bad Management Theories Are Destroying Good Management Practices.' Academy of Management Learning and Education, 4:1, 75-91. 
Gowthorpe, C., Blake, J. \& Dowds, J. 2002. 'Testing the bases of ethical decision making: a study of the New Zealand auditing profession,' Business Ethics: A European Review, 11: 2, 143-156.

Gray, R.H., Bebbington, J. \& McPhail, K. 1994. 'Teaching ethics and the ethics of teaching: educating for immorality and a possible case for social and environmental accounting.' Accounting Education, 3: 1, 51-75.

HMSO. 1977. The Future of Company Reports: A Consultative Document. London: HMSO.

Humphrey, C., Lewis, L. \& Owen, D. 1996. 'Still too distant voices? conversations and reflections on the social relevance of accounting education.' Critical Perspectives On Accounting, 7:1, 77-99.

Hutton, W. 1996. The State We're In. London: Jonathan Cape.

International Accounting Standards Committee Foundation (IASCF). 1989. Framework for the Preparation and Presentation of Financial Statements. London: IASCF.

Kennedy, B.P., Kawachi, I., Prothrow-Stith, D., Lochner, K. \& Gupta, V. 1998 'Social capital, income inequality, and firearm violent crime.' Social Science \& Medicine, 47:1, 7-17.

Krueger, R.A. \& Casey M.A. 2000. Focus Groups: A Practical Guide for Applied Research (3rd Edition). London: Sage.

Loeb S.E. 1991. "The evaluation of "outcomes" of accounting ethics education' Journal of Business Ethics, 10: 2, 77-84.

Loeb S.E. 1988. 'Teaching students accounting ethics: some crucial issues.' Issues in Accounting Education, 3:2, 316-329.

Lombardi, L.G. 1985. 'A quick justification for business ethics.' Journal of Business Ethics, 4: 4, 353-356.

McDonald, G. 2005. 'A case example: integrating ethics into the academic business curriculum.' Journal of Business Ethics, 54:4, 371-384.

McDowell, B. 2000. Ethics and Excuses: the Crisis in Professional Responsibility. London: Quorum books.

McPhail, K.J. \& Gray, R.H. 1996. 'Not Developing Ethical Maturity In Accounting Education: Hegemony, Dissonance And Homogeneity In Accounting Students' World Views.' Dundee University Discussion Paper, ACC/9605.

Marnburg, E. 2003. 'Educational impacts on academic business practitioner's moral reasoning and behaviourl: effects of short courses in ethics and philosophy.' Business Ethics: A European Review, 12:4, 403-413. 
Mir, A. 2003. 'The hegemonic discourse of management texts.' Journal of Management Education, 27: 6, 734-738.

Neimark, M.K. 1995. 'The selling of ethics: the ethics of business meets the business of ethics.' Accounting, Auditing and Accountability, 8:3, 81-96.

Pilling, D. \& Atkins, R. (2009) 'A quest for other ways.' Financial Times, Available at: http://www.ft.com/cms/s/0/17aa8b48-118d-11de$\underline{87 \mathrm{~b} 10000779 \mathrm{fd} 2 \mathrm{ac}, \mathrm{dwp} \text { uuid }=\mathrm{ae} 1104 \mathrm{cc}-\mathrm{f82e}-11 \mathrm{dd}-\mathrm{aae} 8-000077 \mathrm{~b} 07658 . \mathrm{html}}$ [Accessed 20 ${ }^{\text {th }}$ June 2009].

Perriton, L. 2007. 'Really useful knowledge? Critical management education in the UK and US.' Scandinavian Journal of Management, 23: 1, 66-83.

Schleef, D. 1998. 'Empty ethics and reasonable responsibility: vocabularies of motive among law and business students.' Law and Social Inquiry, 22, 619-650.

Sims, R. \& Sims, S. 1991. 'Increasing applied business ethics courses in business school curricula.' Journal of Business Ethics, 10: 3, 211-219.

Springett, D. 2005. 'Education for sustainability in the business studies curriculum: a call for a critical agenda.' Business Strategy and the Environment, 14, 146-159.

Thompson, J.B. 1990. Ideology and Modern Culture: Critical Social Theory In The Era Of Mass Communication. Cambridge: Polity Press.

Van Dijk, T. 1998. 'Critical discourse analysis' in Tannen, D., Schiffrin, D. \& Hamilton, H. (Eds.), Handbook of Discourse Analysis. London: Blackwell.

Waddock, S. 2005. 'Hollow men and women at the helm... hollow accounting ethics.' Issues in Accounting Education, 20: 2, 145-150.

Waddock, S. 2004. 'Hollow men at the helm.' BizEd, July/August, 24-30

Weber, J. 1990. 'Measuring the impact of teaching ethics to future managers: A review assessment and recommendations'. Journal of Business Ethics, 9:2 183-190.

Wilkinson, R. (2005) The Impact of Inequality. London: Routeledge

Wilkinson, R. \& Pickett, K. 2009. The Spirit Level: Why More Equal Societies Almost Always Do Better. London: Allen Lane.

Wolf, M. 2009. 'Seeds of its own destruction.' Financial Times, Available at: http://www.ft.com/cms/s/0/c6c5bd36-0c0c-11de-b87d-

0000779fd2ac,dwp uuid=ae1104cc-f82e-11dd-aae8-000077b07658.html [Accessed $20^{\text {th }}$ June 2009].

Wolfe, A. 1993. 'We've had enough business ethics.' Business Horizons, May-June, $1-3$ 
Table 1 Contextual Information Relating to Research Sites

\begin{tabular}{|c|c|c|c|c|}
\hline & University A & University B & University C & Professional \\
\hline $\begin{array}{r}\text { Number of } \\
\text { Students in Focus } \\
\text { Groups }\end{array}$ & 6 & 5 & 6 & 4 \\
\hline Gender Split & $\begin{array}{c}1 \text { male } \\
5 \text { female }\end{array}$ & $\begin{array}{c}3 \text { male } \\
2 \text { female }\end{array}$ & $\begin{array}{c}2 \text { male } \\
4 \text { female }\end{array}$ & $\begin{array}{c}2 \text { male } \\
2 \text { female }\end{array}$ \\
\hline Institution & Old university & New university & Old university & $\mathrm{N} / \mathrm{A}$ \\
\hline $\begin{array}{r}\text { Specialism of } \\
\text { student }\end{array}$ & Accounting & Accounting & $\begin{array}{l}\text { Mix of accounting } \\
\text { and non- } \\
\text { accounting }\end{array}$ & Accounting \\
\hline $\begin{array}{r}\text { Accreditation } \\
\text { status }\end{array}$ & Full accreditation & Full accreditation & Full accreditation & $\mathrm{N} / \mathrm{A}$ \\
\hline Contact hours & $\begin{array}{c}\text { 43hrs (27 lecture; } \\
16 \text { tutorial) }\end{array}$ & $\begin{array}{c}\text { 22hrs (11 lecture; } \\
11 \text { tutorial) }\end{array}$ & $\begin{array}{c}\text { 16hrs (11 lecture; } \\
5 \text { tutorial) }\end{array}$ & $9 \mathrm{hrs}$ \\
\hline $\begin{array}{r}\text { Recommended } \\
\text { textbook }\end{array}$ & $\begin{array}{c}\text { Wood \& Sangster } \\
(2005)\end{array}$ & Black (2005) & $\begin{array}{c}\text { Britton \& } \\
\text { Waterston }(2003)\end{array}$ & In-house materials \\
\hline
\end{tabular}

Note: This table provides contextual information in relation to the introductory accounting courses taught at three Universities as well as for the Professional body. The first row shows the number of participants in each of the focus groups while the second row shows the mix of male and female participants. The third row describes the type of institution where the focus groups were undertaken i.e. whether it was an old/traditional university or a new university/former polytechnic. The forth row indicates the type of student typically enrolled at each of the different sites. "Accounting" denotes that predominantly accounting undergraduates are enrolled on a course, whereas "mix of accounting and non-accounting" denotes that the course is composed of students from across business disciplines. The fifth row describes the accreditation status of each site - i.e. whether the accounting course is accredited by the professional accounting bodies in the UK. The sixth row describes the contact hours at each site while the final row provides information in relation to the recommend course materials at each site. 
1 The authors wish to draw a distinction between what have been broadly categorised as AngloAmerican models of capitalism (for example Britain and the USA) and "Rhenish"capitalism (for example, social market Europe and Japan) (Dore et al. 1999: 102). This distinction is often neglected in extant critiques of business and accounting, often implying that "capitalism" is a relatively monolithic and homogenous economic structure. While the Anglo-American variant is "commonly regarded as the most individualistic and libertarian of all", the Rhenish model is less market based with a greater deal of co-operation between capital and labour (Hutton 1996; 258; see also, Collison 2003, Dore et al. 1999). One specific distinction between these models bears a particular significance to the arguments developed throughout this paper: that a "key" feature of Anglo-American capitalism is its "preoccupation with maximising shareholder value" (Collison 2003: 854). In other words, AngloAmerican capitalism institutionalises the maximisation of the interests of one particular constituency in society.

${ }^{2}$ In many respects, the implications of such criticisms can be linked to McDowell's (2000) study into the causes of the crisis in professional ethics. For McDowell (2000, p.6) "much unethical activity by professionals is... caused by dysfuntional social structures or by questionable contemporary cultural values".

${ }^{3}$ While Wolfe (1993) and Ghoshal (2005) question the efficacy of "bolt on" courses in business ethics, there exists a body of research which reports that such courses have led to improvements in ethical attitudes and reasoning ability (Weber 1990, Felton \& Sim 2005, Marnburg 2003) although the results of such studies have been contested (Glenn 1992).

4 Thompson (1990: 62) refers to "dissimulation" as a mode of ideology which sustains relations of domination by being "concealed, denied or obscured, or by being represented in a way which deflects attention from or glosses over existing relations or processes". It could be argued that accounting education obscures relations of power through its "guise" of technical rationality (Gray et al. 1994).

${ }^{5}$ The four sites were selected in order to survey a range of accounting students. The three university institutions selected differed in terms of location, the type of institution and the type of student typically enrolled on an introductory financial accounting course. More specifically, University A was an 'old' university in Scotland with predominantly accounting undergraduates enrolled on the introductory financial accounting module. University B was a 'new' university in Scotland, attracting typically local students, and offering a more professionally-orientated degree to predominantly accounting undergraduate students. University $C$ was an 'old' university in the North of England with a mix of accounting and non-accounting students on the introductory financial accounting module. In order to provide a comparison with university undergraduate experiences, the non-accredited degree holders studying for their first financial accounting examination with a professional accounting institute were surveyed in the same way using the same questionnaire instrument. In its totality, the larger project explored the ideological characteristics of accounting education, focusing on the production, content and reception of teaching materials. Drawing on Thompson's (1990) "depth-hermeneutical framework" it was felt that by using four research sites, the linkages between production, content and reception would become more apparent, making more explicit how ideology operates within a particular context.

${ }^{6}$ One way of challenging students' preconceived ideas regarding whom they believe organisations should be accountable to, would be to highlight how these issues have been contested in the past. For example, in the UK, there has been a long tradition of debate surrounding the primacy accorded to shareholders with regard to financial reporting. In the 1970's, the Labour government in the UK considered proposals for organizations to be accountable to a broad range of stakeholders. They produced a Green Paper entitled 'The Future of Company Reports' published in July 1977 (HMSO, 1977). Amongst other things, the Green Paper outlined a requirement to report to a wider group of stakeholders such as employees, customers, the public etc., as well as making it a requirement to include value added statements in company accounts. The Green Paper was part of, and influenced by, wider public debate on this issue - which is perhaps exemplified by the publication of another seminal paper, "The Corporate Report" (ASC, 1975). However, following the defeat of the Labour government in the 1979 general election, the Green Paper was scrapped by the succeeding conservative Prime Minister, Margaret Thatcher. 